\title{
CREATING A CONSTRUCTION SCHEDULE SPECYFING FUZZY NORMS AND THE NUMBER OF WORKERS
}

\author{
E. PLEBANKIEWICZ ${ }^{1}$, P. KARCIŃSKA ${ }^{2}$
}

\begin{abstract}
The basic element of a project organizing construction works is a schedule. The preparation of the data necessary to specify the timings of the construction completion as indicated in the schedule involves information that is uncertain and hard to quantify. The article presents the methods of building a schedule which includes a fuzzy amount of labour, time standards and number of workers. The proposed procedure allows determining the real deadline for project completion, taking into account variable factors affecting the duration of the individual works.
\end{abstract}

Keywords: schedule, scheduling methods, works duration time, fuzzy logic

\section{INTRODUCTION}

Plans of the completion of investment projects are included in the construction organization project, usually in the form of schedules which graphically depict the organization and technology used for the implementation of an investment project in the time function. When preparing a schedule, one needs to consider every stage of its creation in order to gain an optimal effect as close to reality as possible.

The article presents the classical approach to the preparation of a plan of the investment project involving the use of the fuzzy numbers theory at the stage of specifying the amount of work, time standards and the number of workers, and at the stage of estimating the completion timings of individual tasks by turns. Subsequently, reasons for the adoption of this approach are provided andillustrated by a number of practical examples of the model's application.

\footnotetext{
${ }^{1}$ Prof., Eng., Cracow University of Technology, Faculty of Civil Engineering, Warszawska 24, 30-155 Cracow, Poland, e-mail: eplebank@izwbit.pk.edu.pl

${ }^{2}$ MSc., Eng., Cracow University of Technology, Faculty of Civil Engineering, Warszawska 24, 30-155 Cracow, Poland, e-mail: pkarcinska@izwbit.pk.edu.pl
} 


\section{THE IMPLEMENTATION OF FUZZY SETS IN CREATING AND MODIFYING CONSTRUCTION SCHEDULES}

When beginning to create a schedule of planned construction works, all the necessary tasks are usually divided into several stages. The issues of choosing workers and estimating the tasks completion timings belong to these elements which may cause the most uncertainty at the construction completion planning stage. For this reason they were assumed as the critical elements in the process of creating a work progress schedule.

If one assumes that harmonization specifies an appropriate selection of contractors for the particular tasks connected with the investment project and their synchronization in time, then during the preparation of the schedule one should, in the first place, pay attention to three issues [14]:

- allocating resources for the task to be completed (resource allocation);

- specifying the order of task completions which are independent from the technological point of view but must be tackled successively for organizational reasons (task ranking);

- determining a calendar of task completion (time analysis).

These issues should be solved in the comprehensive way taking into account all the interrelations and dependencies. Typically, a single advantageous solution to only one of the issues never leads to the creation of a good schedule.

Many factors that influence the creation of a schedule are imprecise and hard to quantify. To tackle this sort of tasks fuzzy logic proves especially useful $[11,18]$. Many studies attempted to employ the fuzzy sets theory to create construction schedules.

Authors of $[7,8]$ presented the problem of a schedule preparation that ensured the maximization of the probability of completing a construction in time no longer than the time required, taking into consideration the assumed probability of fulfilling an imprecisely specified limit of accessibility to a particular resource. [9] used the fuzzy sets theory in scheduling construction works by means of the Critical Chain Method.

[15] presented a method which offers insight into the possible deviations and the risk associated with the cost and time of project's completion, as the deviation function and the probability of its occurrence. Using the operations encompassed by the scope of the fuzzy sets theory, the values of deviation and of the risk connected with the cost and time of the investment project were obtained. The article [8] described the method of fuzzy modelling of the influence of the anticipated interferences on the construction completion time when the data characterising the conditions of the 
construction were uncertain. The implementation of fuzzy reasoning and fuzzy relations allowed take into account the relations between the possible lengthening of a particular construction time and its sensitivity to the effect of certain factors and subjectively, the influence of the interference on the construction completion time.

In [1] authors analysed the implementation of fuzzy sets in schedule planning when time, costs and resources were limited. [12] presented the usage of fuzzy sets for the assessment of uncertainty caused by the duration of a construction project. In these works fuzzy sets are an alternative to the theory of probability.

In the paper [6], there was an attempt to introduce the fuzzy random theory into the problem of project scheduling for subscribing the complicated environment with the co-existing uncertainty of randomness and fuzziness. Three types of fuzzy random models, namely: (i) the expected cost minimization model, (ii) the $(\alpha, \beta)$-cost minimization model and (iii) the chance maximization model, were built to meet the optimization requirements of decision-makers with different preferences. The problem solved in this paper can be regarded as the extension of the project scheduling problem in a single uncertain environment with randomness or fuzziness, since the fuzzy random models can be degenerated to random models and fuzzy models, respectively. A hybrid intelligent algorithm integrating fuzzy random simulations and GA was also introduced.

\section{ELEMENTS OF FUZZY SETS USED IN SCHEDULE MAKING}

In the schema of schedule making proposed in the present article, the notion of the fuzzy number is used. In literature one may find a number of definitions for a fuzzy number. One of the most detailed definitions was proposed by Goetschel and Voxmann [3]. A fuzzy number $A$ is a specific type of a fuzzy set determined on the set of real numbers $(X=\mathrm{R})$, which, additionally, fulfils the following conditions:

- is normal;

a set is normal when there exists an argument for which the function takes the value 1;

- is convex, set $\mathrm{A}$ is convex when

$$
\forall x, y \in X \quad \forall \lambda \in[0 ; 1] \quad \mu_{A}(\lambda \cdot x+(1-\lambda) \cdot y) \geq \min \left(\mu_{A}(x), \mu_{A}(y)\right)
$$

- function support $\mu_{\mathrm{A}}(\mathrm{x})$ is an interval;

- $\mu_{\mathrm{A}}(\mathrm{x})$ is a continuous interval function. 
The model uses the fuzzy numbers with trapezoid and triangular diagrams. The fuzzy number with the trapezoid function is depicted in Fig. 1.

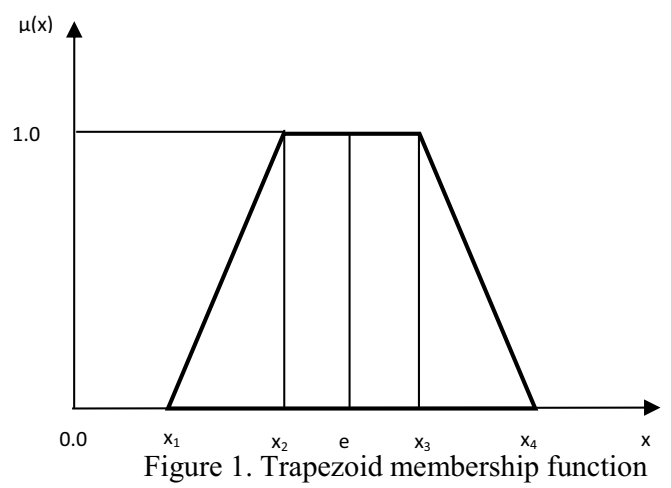

A description of a trapezoid membership function is also presented in literature by a table of values (Eq. 3.1).

$$
\mu_{\mathrm{A}}(\mathrm{x})=\left\{\begin{array}{lc}
0, & x<x_{1} \\
\left(x-x_{1}\right) /\left(x_{2}-x_{1}\right), & x_{1}<x<x_{2} \\
1, & x_{2}<x<x_{3} \\
\left(x_{4}-x\right) /\left(x_{4}-x_{3}\right), & x_{3}<x<x_{4} \\
0, & x>x_{4}
\end{array}\right.
$$

The fuzzy number with a triangular diagram is presented in Fig. 2.

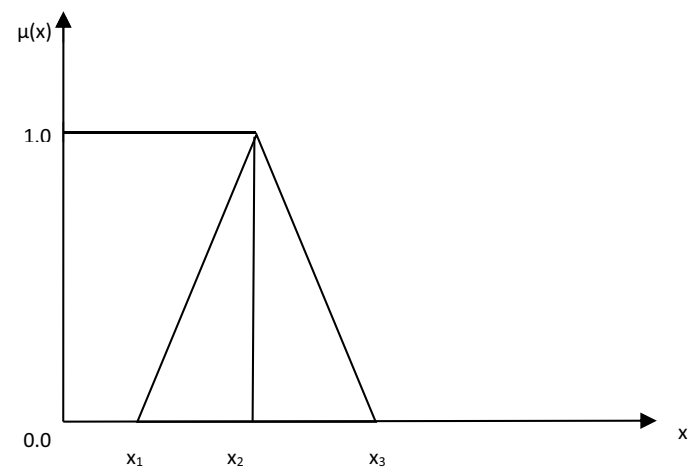

Figure 2. Triangular membership function 
The description of the triangular membership function is also presented in literature in a table of values as in formula 3.2 below.

$$
\mu_{\mathrm{A}}(\mathrm{x})=\left\{\begin{array}{lc}
0, & x<x_{1} \\
\left(x-x_{1}\right) /\left(x_{2}-x_{1}\right), & x_{1}<x<x_{2} \\
\left(x_{3}-x\right) /\left(x_{3}-x_{2}\right), & x_{2}<x<x_{3} \\
0, & x>x_{3}
\end{array}\right.
$$

The fuzzy number can also be interpreted as the four $\left\{\mathrm{x}_{1}, \mathrm{x}_{2}, \mathrm{x}_{3}, \mathrm{x}_{4}\right\} . \mathrm{x}_{2}$ and $\mathrm{x}_{3}$ indicate the interval in which the membership function has the value $1 . \mathrm{x}_{1}$ and $\mathrm{x}_{4}$ relate to the left-hand endpoint and the right-hand endpoint of the membership function respectively.

The fuzzy number of the trapezoid diagram can be, therefore, unambiguously specified as a problem of four ordered numbers and recorded as:

$$
\mathrm{X}=\left\{\mathrm{x}_{1}, \mathrm{x}_{2}, \mathrm{x}_{3}, \mathrm{x}_{4}\right\}
$$

A fuzzy number with a triangular diagram can be unambiguously specified as a problem of four ordered numbers and recorded as:

$$
\mathrm{X}=\left\{\mathrm{x}_{1}, \mathrm{x}_{2}, \mathrm{x}_{2}, \mathrm{x}_{3}\right\}
$$

On two fuzzy numbers, $A=\left\{a_{1}, a_{2}, a_{3}, a_{4}\right\}$ and $B=\left\{b_{1}, b_{2}, b_{3}, b_{4}\right\}$, one can perform an operation of addition, subtraction, multiplication and division. They are illustrated by formulas $3.5,3.6,3.7,3.8$ [5].

Addition:

$$
\begin{aligned}
& A \oplus B=\left(a_{1}, a_{2}, a_{3}, a_{4}\right) \oplus\left(b_{1}, b_{2}, b_{3}, b_{4}\right) \\
& =\left(a_{1}+b_{1}, a_{2}+b_{2}, a_{3}+b_{3}, a_{4}+b_{4}\right)
\end{aligned}
$$

Subtraction:

$$
\begin{aligned}
& A(-) B=\left(a_{1}, a_{2}, a_{3}, a_{4}\right)(-)\left(b_{1}, b_{2}, b_{3}, b_{4}\right) \\
& =\left(a_{1}-b_{4}, a_{2}-b_{3}, a_{3}-b_{2}, a_{4}-b_{1}\right)
\end{aligned}
$$


Multiplication:

$$
A \otimes B=\left(a_{1}, a_{2}, a_{3}, a_{4}\right) \otimes\left(b_{1}, b_{2}, b_{3}, b_{4}\right)=\left(a_{1} b_{1}, a_{2} b_{2}, a_{3} b_{3}, a_{4} b_{4}\right)
$$

Division:

$$
A(\cdot) B=\left(a_{1}, a_{2}, a_{3}, a_{4}\right)(\cdot)\left(b_{1}, b_{2}, b_{3}, b_{4}\right)=\left(a_{1} / b_{4}, a_{2} / b_{3}, a_{3} / b_{2}, a_{4} / b_{1}\right)
$$

For the fuzzy number specified in Fig. 1 the sharpening value can be specified as follows [5]:

$$
e=\left(x_{1}+x_{2}+x_{3}+x_{4}\right) / 4
$$

For the fuzzy number specified in figure 2 the sharpening value can be specified as follows [5]:

$$
e=\left(x_{1}+2 x_{2}+x_{3}\right) / 4
$$

\section{THE FOUNDATIONS OF A SCHEDULE BASED ON FUZZY SETS}

The base of constructing a schedule is, after establishing the type and the scope of the tasks involved in it, specifying the completion time. In the case of a schedule concerning the completion of a building (that is, an overall progress schedule) the completion time can be specified when the standard work time for a given construction work, the amount of labour and the number of workers involved in the completion of the task are given.

All these components are vital for the assessment of the completion time, but are also hard to specify unambiguously at the investment preparation and schedule building stage. Time standards can be found in various catalogues. Typically, they include specific organizational, technological and equipment-related solutions which, at the investment preparation stage, are even more difficult to predict. What is worth noticing is the fact that the costs of man-hours and machine hours available in the database of standards differ from one catalogue to another; moreover, they are adjusted to an average team of builders working under average conditions. Both the team and the conditions on the construction site may not be average. Thus applying the same calculation of costs for each individual case will not precisely reflect the reality. For this reason the model proposed here specifies the standard as a fuzzy number. The standard necessary to establish the completion 
time was specified as a fuzzy number of the trapezoid diagram. In practice, one may use various standard values taken from different catalogues, taking into consideration a variety of technologies and machines.

The next component involves the amount of labour. Most frequently a schedule includes the amount of labour resulting from the cost calculation. The amount resulting from the project documentation does not always have the same value in reality. This is caused by a variety of factors, such as imprecise documentation, calculation errors, conditions different than those assumed, for instance, groundwater conditions in earth works, or changes added by the investor. Depending on the type of construction works, there exists a diverse risk of a change in the amount of works. The risk is the greatest in, for example, earthworks. The model proposed in the article employs the triangular membership function, as it is assumed that the value of the membership functions $=1$ is the value resulting from the cost calculation.

The number of construction workers is often treated as constant, although in reality it relies on many factors. Researchers from various countries have focused on such factors influencing employment of workers for construction projects. One of the most extensive studies into this issue was performed in 2008 in Hong Kong on the basis of 54 projects [21].

The construction method of an individual project determines the site labour input and the mix of skills. The increasing use of prefabrication, production activities off-site, and the use of other engineering demanding construction methods would cause an increase in plant and equipment operators and prefabricated elements erectors. The degree of utilization of mechanization and automation also critically influences the labour demand at site level as labor and capital are the major inputs. In general, the greater the input of capital, the less labour is required because automation tends to be labour saving. Labour requirements can also be affected by the management skills of the project team. Better coordination and utilization of the plant and labour on sites leads to a reduction in the manpower requirements.

In Poland a study into the factors influencing employment planning was performed by the authors of the present article. 11 factors were evaluated. The results revealed that the most influential factors included the imposed deadlines for the completion of individual works, the contracted deadline of construction completion, the amount of labour and the technology of construction completion. The least influential factors were the availability of workers, the degree of cooperation between the designer and the contractor, and the value of the contract. The comparison of the Polish and the Hong Kong study has shown that in the latter the factor involving the contract value was 
rated really high. The difference might be caused by the fact that contract value is not directly associated with employment and that this sort of influence is not always present.

Due to the variety of influences on the number of workers, the number may be specified in a nondeterministic way, using the fuzzy sets and fuzzy numbers theory. It is suggested that the number of workers should be the fuzzy number of the trapezoid diagram.

Therefore, the construction completion time may be specified as:

$$
\mathrm{T}_{\mathrm{i}}=\mathrm{n}_{\mathrm{i}} * \mathrm{~L}_{\mathrm{i}} / \mathrm{r}_{\mathrm{i}}
$$

Where: $T_{i}$ indicates the time of works completion $i ; n_{i}-$ the standard (that is, the number of work units completed in a time unit); $L_{i}-$ the number of works; $r_{i}-$ the number of workers employed to complete the work $\mathrm{i}$.

Assuming that the standard and the number of workers are fuzzy numbers with the trapezoid membership function, and the number of works is a fuzzy number with a triangular membership function, the following symbols will be used:

$$
\begin{aligned}
\mathrm{N}_{\mathrm{i}} & =\left(\mathrm{n}_{\mathrm{i} 1} ; \mathrm{n}_{\mathrm{i} 2} ; \mathrm{n}_{\mathrm{i} 3} ; \mathrm{n}_{\mathrm{i} 4}\right) \\
\mathrm{L}_{\mathrm{i}} & =\left(\mathrm{l}_{11} ; \mathrm{l}_{\mathrm{i} 2} ; \mathrm{l}_{\mathrm{i} 2} ; \mathrm{l}_{\mathrm{i} 3}\right) \\
\mathrm{R}_{\mathrm{i}} & =\left(\mathrm{r}_{\mathrm{i} 1} ; \mathrm{r}_{\mathrm{i} 2} ; \mathrm{r}_{\mathrm{i} 3} ; \mathrm{r}_{\mathrm{i} 4}\right)
\end{aligned}
$$

In accordancewith the Eq. 3.7, the product of the standard and the number of works can be calculated as follows:

$$
\mathrm{N}_{\mathrm{i}} * \mathrm{~L}_{\mathrm{i}}=\left(\mathrm{n}_{\mathrm{i} 1} \mathrm{l}_{\mathrm{i} 1} ; \mathrm{n}_{\mathrm{i} 2} \mathrm{l}_{\mathrm{i} 2} ; \mathrm{n}_{\mathrm{i} 3} \mathrm{l}_{\mathrm{i} 2} ; \mathrm{n}_{\mathrm{i} 4} \mathrm{l}_{\mathrm{i} 3}\right)=\left(\mathrm{nl}_{\mathrm{i} 11} ; \mathrm{nl}_{\mathrm{i} 22} ; \mathrm{nl}_{\mathrm{i} 32} ; \mathrm{nl}_{\mathrm{i} 43}\right)
$$

The time of construction completion can be calculated according to the Eq. 4.1:

$$
\mathrm{T}_{\mathrm{i}}=\mathrm{N}_{\mathrm{i}} * \mathrm{~L}_{\mathrm{i}} / \mathrm{R}_{\mathrm{i}}=\left(\mathrm{nl}_{\mathrm{i} 11} / \mathrm{r}_{\mathrm{i} 4} ; \mathrm{nl}_{\mathrm{i} 22} / \mathrm{r}_{\mathrm{i} 3} ; \mathrm{nl}_{\mathrm{i} 32} / \mathrm{r}_{\mathrm{i} 2} ; \mathrm{nl}_{\mathrm{i} 43} / \mathrm{r}_{\mathrm{i} 1}\right)=\left(\mathrm{t}_{\mathrm{i} 1} ; \mathrm{t}_{\mathrm{i} 2} ; \mathrm{t}_{\mathrm{i} 3} ; \mathrm{t}_{\mathrm{i} 4}\right)
$$

\section{AN EXAMPLE OF THE APPLICATION OF THE MODEL}

The article assumes that the construction project can be mapped on a one-point network of relations of one initial action $\mathrm{S}$ indicating the beginning of the construction with one final action $\mathrm{F}$ meaning the completion of a construction. The analysis encompassed actions connected with relationships of the completion-beginning type, as in Fig. 3. 


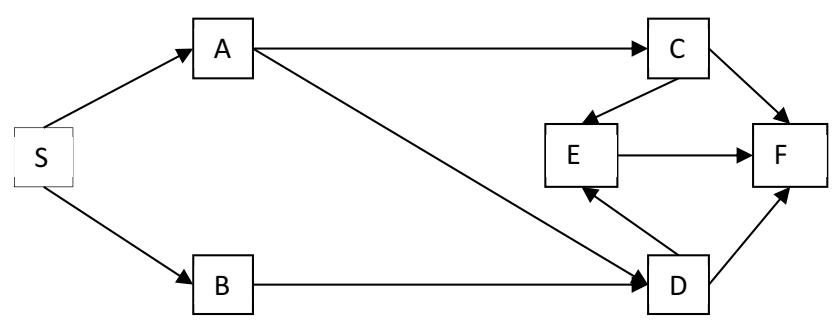

Figure 3. One - point network of relations used in the example

For each individual activity (that is, construction works) the assumptions were as follows:

Work A:

Standard $(1,98 ; 2,01 ; 2,33 ; 2,5)$ man-hour $/ \mathrm{m}^{3}$

Number of works $(80 ; 90 ; 140) \mathrm{m}^{3}$

Work B:

Standard $(1,98 ; 2,01 ; 2,33 ; 2,5) \mathrm{m}-\mathrm{h} / \mathrm{m}^{3}$

Number of works $(100 ; 120 ; 180) \mathrm{m}^{3}$

Work C:

Standard $(2,4 ; 3,4 ; 4,1 ; 4,9) \mathrm{m}-\mathrm{h} / \mathrm{m}^{2}$

Number of works $(240 ; 280 ; 300) \mathrm{m}^{2}$

Work D:

Standard $(5,1 ; 5,3 ; 5,4 ; 5,8) \mathrm{m}-\mathrm{h} / \mathrm{m}^{3}$

Number of works $(450 ; 460 ; 500) \mathrm{m}^{3}$

Work E:

Standard $(0,12 ; 0,24 ; 0,34,0,4) \mathrm{m}-\mathrm{h} / \mathrm{m}^{3}$

Number of works $(54 ; 63 ; 80) \mathrm{m}^{3}$

For every work it was assumed that the number of workers is a fuzzy number $X=\left\{x_{1}, x_{2}, x_{3}, x_{4}\right\}$. In accordance with Eq. 4.1, the following work completion times were established (Table 1).

Table 1. Fuzzy figures in the relationship network according to Figure 3

\begin{tabular}{|c|c|c|c|c|}
\hline Work & Standard & Number of works & $\begin{array}{c}\text { Number of } \\
\text { workers }\end{array}$ & Completion time \\
\hline A & $(1,98 ; 2,01 ; 2,33 ; 2,50)$ & $(80 ; 90 ; 140)$ & $(5 ; 6 ; 7 ; 8)$ & $(2 ; 3 ; 4 ; 9)$ \\
\hline B & $(1,98 ; 2,01 ; 2,33 ; 2,50)$ & $(100 ; 120 ; 180)$ & $(5 ; 6 ; 7 ; 8)$ & $(3 ; 4 ; 6 ; 11)$ \\
\hline C & $(2,40 ; 3,40 ; 4,10 ; 4,90)$ & $(190 ; 220 ; 260)$ & $(5 ; 6 ; 7 ; 8)$ & $(7 ; 13 ; 19 ; 32)$ \\
\hline D & $(5,10 ; 5,30 ; 5,40 ; 5,80)$ & $(62 ; 68 ; 70)$ & $(5 ; 6 ; 7 ; 8)$ & $(5 ; 6 ; 8 ; 10)$ \\
\hline E & $(0,12 ; 0,24 ; 0,34 ; 0,40)$ & $(340 ; 390 ; 420)$ & $(5 ; 6 ; 7 ; 8)$ & $(1 ; 2 ; 3 ; 4)$ \\
\hline
\end{tabular}


Table 2 presents the results of calculations of the earliest and the latest fuzzy project completion deadlines. The calculations were performed in accordance with Eq. 4.1.

Table 2. Summary of calculation results on the basis of Table 1

\begin{tabular}{|c|c|c|c|c|c|}
\hline \multirow{2}{*}{ Work } & \multicolumn{2}{|c|}{ The earliest fuzzy deadlines } & \multirow{2}{*}{ Reserve time } & \multicolumn{2}{|c|}{ The latest fuzzy deadlines } \\
\cline { 2 - 3 } & of beginning & of completion & & of beginning & of completion \\
\hline S & $(0,0,0,0)$ & $(0,0,0,0)$ & $(0,0,0,0)$ & $(0,0,0,0)$ & $(0,0,0,0)$ \\
\hline A & $(0,0,0,0)$ & $(2,3,4,9)$ & $(0,0,0,0)$ & $(0,0,0,0)$ & $(2,3,4,9)$ \\
\hline B & $(0,0,0,0)$ & $(3,4,6,11)$ & $(1,6,9,20)$ & $(1,6,9,20)$ & $(4,10,15,31)$ \\
\hline C & $(2,3,4,9)$ & $(9,16,23,41)$ & $(0,0,0,0)$ & $(2,3,4,9)$ & $(9,16,23,41)$ \\
\hline D & $(3,4,6,11)$ & $(8,10,14,21)$ & $(1,6,9,20)$ & $(4,10,15,31)$ & $(9,16,23,41)$ \\
\hline E & $(9,16,23,41)$ & $(10,18,26,45)$ & $(0,0,0,0)$ & $(9,16,23,41)$ & $(10,18,26,45)$ \\
\hline F & $(10,18,26,45)$ & $(10,18,26,45)$ & $(0,0,0,0)$ & $(10,18,26,45)$ & $(10,18,26,45)$ \\
\hline
\end{tabular}

The proposed method solving the issue discussed in the article consists of a two-stage preparation of a construction project schedule. During the first stage a fuzzy schedule is created (Fig. 4 and 5), then during the second stage, on the basis of the fuzzy schedule, an ordinary non-fuzzy one is made (Fig. 6).

Table 3 depicts the results of calculations performed after sharpening obtained by means of the sharpening operator according to Eq. 3.9, which assigns a real number to the values of fuzzy variables. The results are used to construct an ordinary schedule which has been obtained from a fuzzy one.

Table 3. Summary of calculation results after sharpening

\begin{tabular}{|c|c|c|c|c|c|}
\hline \multirow{2}{*}{$\begin{array}{c}\text { Wor } \\
\mathrm{k}\end{array}$} & \multicolumn{2}{|c|}{ The earliest deadlines } & \multirow{2}{*}{ Reserve time } & \multicolumn{2}{|c|}{ The latest deadlines } \\
\hline & of beginning & of completion & & of beginning & of completion \\
\hline $\mathrm{S}$ & 0 & 0 & 0 & 0 & 0 \\
\hline A & 0 & 4,5 & 0 & 0 & 4,5 \\
\hline B & 0 & 6 & 9 & 9 & 15 \\
\hline $\mathrm{C}$ & 4,5 & 22 & 0 & 4,5 & 22 \\
\hline $\mathrm{D}$ & 6 & 13 & 9 & 15 & 22 \\
\hline$E$ & 22 & 25 & 0 & 22 & 25 \\
\hline $\mathrm{F}$ & 25 & 25 & 0 & 25 & 25 \\
\hline
\end{tabular}

S
B
C
D
E
F
O

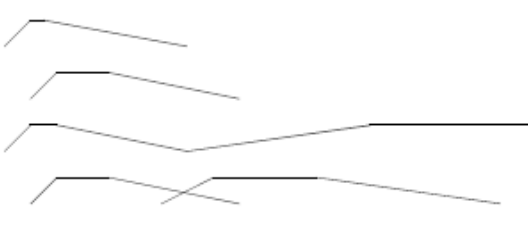

$5 \mid$

$10 \mid$

$15 \mid$

$20 \mid$

$25 \mid$

$30 \mid$

35 |

$40 \mid$

$45 \mid$

Figure 4. Fuzzy schedule according to the earliest deadlines 


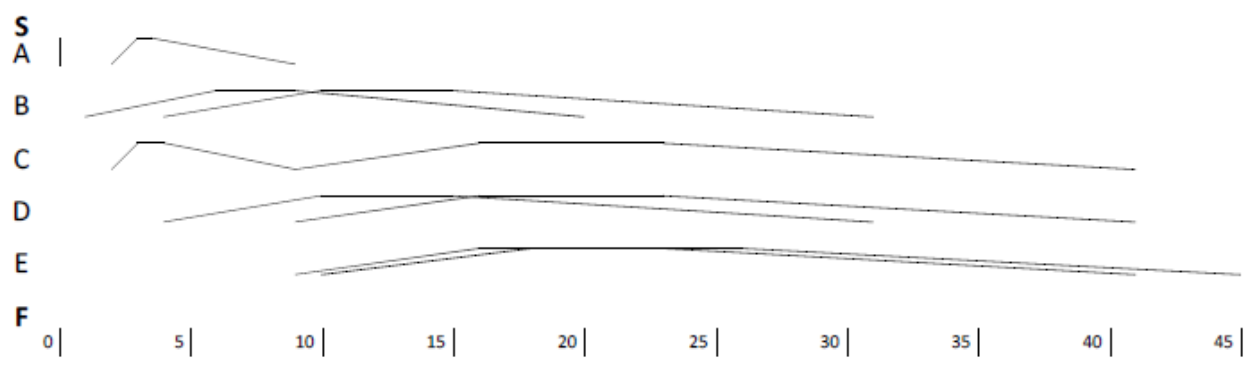

Figure 5. Fuzzy schedule according to the latest deadlines

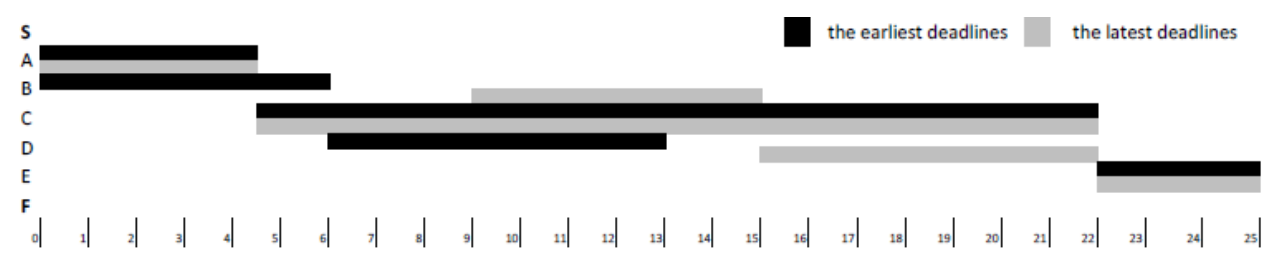

Figure 6. Ordinary schedule obtained from the fuzzy one

Fig. 4 and 5 illustrate a fuzzy schedule for the results summarised in Table 2. The schedules were created for the earliest and the latest deadlines. Fig. 6 depicts an ordinary schedule obtained from the fuzzy one after sharpening (also according to the earliest and the latest deadlines).

For the sake of comparison and proving the validity of the fuzzy sets theory in scheduling, a traditional schedule was prepared on the basis of real deterministic numbers. Thus for the schema compatible with Fig. 1, in order to obtain an ordinary schedule the authors assumed the following:

- as a time standard - the average standard (calculated as an arithmetic average of the four standards provided);

- as the number of workers - a constant deterministic number ( 7 or 6 workers)

- as the amount of labour - the amount resulting directly from the cost calculation.

The data were summarised in Table $4 \mathrm{a}$ where the number of workers was 7 , and then in Table $4 \mathrm{~b}$ where the number of workers was 6.

Table 4a. Non-fuzzy figures for the relationship network according to Figure 3 ( 7 workers)

\begin{tabular}{|c|c|c|c|c|}
\hline Work & Standard & Number of works & $\begin{array}{c}\text { Number of } \\
\text { workers }\end{array}$ & Completion time \\
\hline A & 2,205 & 90 & 7 & 3,5 \\
\hline B & 2,205 & 120 & 7 & 5 \\
\hline C & 3,7 & 220 & 7 & 14,5 \\
\hline D & 5,4 & 68 & 7 & 6,5 \\
\hline E & 0,275 & 390 & 7 & 2 \\
\hline
\end{tabular}


Table 5a. Summary of calculation results based on Table 4a

\begin{tabular}{|c|c|c|c|c|c|}
\hline \multirow{2}{*}{ Work } & \multicolumn{2}{|c|}{ The earliest deadlines } & \multirow{2}{*}{ Reserve time } & \multicolumn{2}{c|}{ The latest deadlines } \\
\cline { 2 - 3 } & of beginning & of completion & & of beginning & of completion \\
\hline S & 0 & 0 & 0 & 0 & 0 \\
\hline A & 0 & 3,5 & 0 & 0 & 3,5 \\
\hline B & 0 & 5 & 6,5 & 6,5 & 11,5 \\
\hline C & 3,5 & 18 & 0 & 3,5 & 18 \\
\hline D & 5 & 11,5 & 6,5 & 11,5 & 18 \\
\hline E & 18 & 20 & 0 & 18 & 20 \\
\hline F & 20 & 20 & 0 & 20 & 20 \\
\hline
\end{tabular}

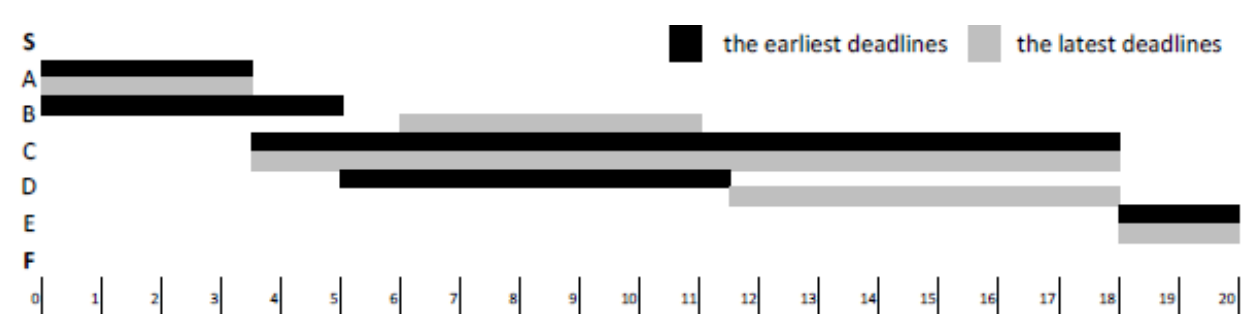

Figure 7. Schedule for the results summarised in Table 5a

Table $4 \mathrm{~b}$. Non-fuzzy figures for the relationship network according to Figure 3 ( 6 workers)

\begin{tabular}{|c|c|c|c|c|}
\hline Work & Standard & Number of works & $\begin{array}{c}\text { Number of } \\
\text { workers }\end{array}$ & Completion time \\
\hline A & 2,205 & 90 & 6 & 4 \\
\hline B & 2,205 & 120 & 6 & 5,5 \\
\hline C & 3,7 & 220 & 6 & 17 \\
\hline D & 5,4 & 68 & 6 & 8 \\
\hline E & 0,275 & 390 & 6 & 2 \\
\hline
\end{tabular}

Table $5 \mathrm{~b}$. Summary of calculation results based on Table $4 \mathrm{~b}$

\begin{tabular}{|c|c|c|c|c|c|}
\hline \multirow{2}{*}{ Work } & \multicolumn{2}{|c|}{ The earliest deadlines } & \multirow{2}{*}{ Reserve time } & \multicolumn{2}{|c|}{ The latest deadlines } \\
\cline { 2 - 3 } & of beginning & of completion & & of beginning & of completion \\
\hline S & 0 & 0 & 0 & 0 & 0 \\
\hline A & 0 & 4 & 0 & 0 & 4 \\
\hline B & 0 & 5,5 & 7,5 & 7,5 & 13 \\
\hline C & 4 & 21 & 0 & 4 & 21 \\
\hline D & 5,5 & 13,5 & 7,5 & 13 & 21 \\
\hline E & 21 & 23 & 0 & 21 & 23 \\
\hline F & 23 & 23 & 0 & 23 & 23 \\
\hline
\end{tabular}

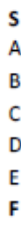

the earliest deadlines

the latest deadlines

d

the latest deadlines

Figure 8. Schedule for the results summarised in Table $5 \mathrm{~b}$ 
When performing calculations on real numbers, one can notice that both the standard and the amount of labour result may be directly taken either from the database of standards available or the cost calculation. The only value that allows manipulating the construction completion time is the value specifying the number of workers. This number, in a sense, results from the planner's assumptions. The comparison of Tables $5 \mathrm{a}$ and $5 \mathrm{~b}$ reveals that changing the constant number of workers only by 1 , changes the project completion time by 3 days. In the case of the sharpened schedule, the completion time is even longer and equals 25 days. Here the workforce is modelled as a fuzzy number $(5,6,7$, and 8$)$, where resource availability equals to about 6.5 , which is comparable to the deterministic example.

\section{CONCLUSiON}

Plans of the investment project completion are included in the construction organization project, usually in the form of schedules. In the case of a work realization schedule (that is, the general schedule of work progress), the execution time of the individual works can be determined on the basis of the standard time of the works, the amount of works and the number of workers performing the task. Taking into consideration the inaccuracy of the data needed to determine the execution time, it is proposed to apply fuzzy numbers in the calculations.

In the example described above, the rules of a fuzzy schedule construction were presented. This approach was contrasted with a traditional schedule, which clearly demonstrated the superiority of the model applying the fuzzy sets theory. Its structure was based on actions conducted from the beginning to the end on real, deterministic numbers. The results indicated that the construction of the fuzzy schedule taking into account variable factors affecting the duration of the individual works allows for a more realistic determination of the project completion deadline. 


\section{REFERENCES}

1. Castro-Lacouture D., Suer A. G., Gonzales-Joaqui J., and Yates J. K., "Construction project scheduling with time, cost, and material restrictions using fuzzy mathematical models and critical path method" Journal of Construction Engineering and Management, October, 1096-1104, 2009.

2. Chao Li-Chung, Hsiao Chih-Sheng, "Fuzzy model for predicting project performance based on procurement experiences" Automation in Construction, 28, 71-81, 2012.

3. Goetschel R., Voxmann W., "Topological properties of fuzzy numbers”, Fuzzy Sets Systems, 9, 31-43,1983.

4. Hapke M., Slowinski R. "Fuzzy priority heuristics for project scheduling" Fuzzy Sets and Systems, 83, 291-299, 1996.

5. Kaufmann A., Gupta M.M., "Introduction to fuzzy arithmetic theory and application", Van Nostrand Reinhold, New York, 1991.

6. Hua K., Weimin M., Junjie M., "Solving project scheduling problem with the philosophy of fuzzy random programming” Fuzzy Optim Decis Making, 11, 296-284, 2012.

7. Kulejewski J., Ibadob N. „Harmonogramowanie budowy z uwzględnieniem rozmytych czasów wykonania robót" Czasopismo Techniczne, 107, 2, 231 - 247, 2010.

8. Kulejewski J., Ibadov N., „Rozmyte modelowanie czasów wykonania robót budowlanych w warunkach niepewności” Czasopismo Techniczne, 107, 2, 139 - 155, 2010.

9. Kulejewski J., Ibadov N., Zieliński B., „Zastosowanie teorii zbiorów rozmytych w harmonogramowaniu robót budowlanych metodą łańcucha krytycznego" Budownictwo i Inżynieria Środowiska, 2, 3, 331 - 338, 2011.

10. Leu Sou-Sen, Chen An-Ting, Yang Chung-Huei, “A GA-based fuzzy optimal model for construction time-cost trade-off' International Journal of Project Management, 19, 47-58, 2001.

11. Leśniak A., Plebankiewicz, E., "The Modeling of the Decision-Making Process Concerning Participation in the Construction Bidding." J. Manage. Eng., 10.1061/(ASCE)ME.1943-5479.0000237 (Jun. 11, 2013), 2013.

12. Liberatore Matthew J. "Project Schedule Uncertainty Analysis Using Fuzzy Logic" Project Management Journal, December, 15-22, 2002.

13. Lorterapong P., Moselhi O., "Project-network analysis using fuzzy sets theory" Journal of Construction Engineering and Management, December, 309-318, 1996.

14. Marcinkowski R. „Metody rozdziału zasobów realizatora w działalności inżynieryjno - budowlanej” Wydawnictwo WAT, Warszawa, 2002.

15. Minasowicz A., Kostrzewa B., „Analiza czasowo - kosztowa planowanego przedsięwzięcia budowlanego przy zastosowaniu zbiorów rozmytych" Budownictwo i Inżynieria Środowiska, 2, 4, 595 - 604, 2011.

16. Ordonez Oliveros Adriana V., Fayek Aminah Robinson "Fuzzy Logic Approach for Activity Delay Analysis and Schedule Updating" Jiurnal of Construction Engineering and Management, January, 42-51, 2005.

17. Ozelkan Ertunga C., Duckstein L., "Optimal fuzzy counterparts of scheduling rules" European Journal of Operational Research, 1999, 113, 593-609, 1999.

18. Plebankiewicz E., "Contractor prequalification model using fuzzy sets", Journal of Civil Engineering and Management, 15, 4, 377-385, 2009.

19. Wang Juite, "A fuzzy project scheduling approach to minimize schedule risk for product development" Fuzzy Sets and Systems, 2002, 127, 99-116, 2004.

20. Wang Juite “A fuzzy scheduling approach for product development projects” European Journal of Perational Research, 152, 180-194.

21. Wong James M. W., Chan Albert P. C., Chiang Y. H. "Modelling and Forecasting Constrction Labor Demand: Multivariate Analysis" Journal of Construction Engineering and Management, September, 2008. 


\section{LIST OF FIGURES AND TABLES:}

Fig. 1. Trapezoid membership function

Rys. 1. Trapezowa funkcja przynależności

Fig. 2. Triangular membership function

Rys. 2. Trójkątna funkcja przynależności

Fig. 3. One - point network of relations used in the example

Rys. 3. Jednopunktowa sieć powiązań wykorzystana w przykładzie

Fig. 4. Fuzzy schedule according to the earliest deadlines

Rys. 4. Harmonogram rozmyty według terminów najwcześniejszych

Fig. 5. Fuzzy schedule according to the latest deadlines

Rys. 5. Harmonogram rozmyty według terminów najpóźniejszych

Fig. 6. Ordinary schedule obtained from the fuzzy one

Rys. 6. Harmonogram zwykły po wyostrzeniu

Fig. 7. Schedule for the results summarised in Table 5a

Rys. 7. Harmonogram dla danych zestawionych w Tabeli 5a

Fig. 8. Schedule for the results summarised in Table $5 \mathrm{~b}$

Rys. 8. Harmonogram dla danych zestawionych w Tabeli 5b

Tab. 1. Fuzzy figures in the relationship network according to Figure 3

Tab. 1. Dane liczbowe rozmyte do sieci powiązań według rys. 3

Tab. 2. Summary of calculation results on the basis of Table 1

Tab. 2. Zestawienie wyników obliczeń na podstawie Tabeli 1

Tab. 3. Summary of calculation results after sharpening

Tab. 3. Zestawienie wyników obliczeń po wyostrzeniu

Tab. 4a. Non-fuzzy figures for the relationship network according to Figure 3 ( 7 workers)

Tab. 4a. Dane liczbowe (nierozmyte) do sieci powiązań według Rysunku 3 (7 pracowników)

Tab. 4b. Non-fuzzy figures for the relationship network according to Figure 3 (6 workers)

Tab. 4b. Dane liczbowe (nierozmyte) do sieci powiązań według Rysunku 3 (6 pracowników)

Tab. 5a. Summary of calculation results based on Table $4 \mathrm{a}$

Tab. 5a. Zestawienie wyników obliczeń na podstawie Tabeli 4a

Tab. 5b. Summary of calculation results based on Table $4 \mathrm{~b}$

Tab. 5b. Zestawienie wyników obliczeń na podstawie Tabeli 4b 


\section{HARMONOGRAMOWANIE ROBÓT BUDOWLANYCH Z OKREŚLENIEM ROZMYTYCH NORM I LICZBY PRACOWNIKÓW}

Slowa kluczowe: harmonogram, metody harmonogramowania, czas realizacji robot, logika rozmyta

\section{STRESZCZENIE:}

Przystępując do budowy harmonogramu planowanych robót budowlanych, wszystkie niezbędne prace dzielimy zazwyczaj na kilka etapów. Podstawą budowy harmonogramu jest po wyznaczeniu rodzaju i zakresu uwzględnionych w nim zadań, określenie czasu ich realizacji. w przypadku harmonogramu dotyczącego realizacji obiektu budowlanego czas realizacji można określić znając normę czasu pracy dla danej roboty, jej ilość oraz liczbę robotników realizujących zadanie. Wszystkie składniki, niezbędne do oszacowania czasu realizacji są trudne do jednoznacznego określenia na etapie przygotowania inwestycji i budowy harmonogramu. Kwestie doboru brygad oraz szacowanie czasu realizacji zadań są elementami, które na etapie opracowywania planu realizacji budowy mogą generować wątpliwości. z tych powodów zostały przyjęte jako elementy newralgiczne w procesie tworzenia harmonogramu postępu robót.

W artykule zaprezentowano metody budowania harmonogramów na podstawie rozmytych wartości norm czasu pracy i liczebności pracowników. Zaproponowana procedura pozwala określić rzeczywisty termin realizacji przedsięwzięcia z uwzględnieniem zmiennych czynników wpływających na czas realizacji poszczególnych robót budowlanych.

Praca została podzielona na trzy główne rozdziały. Pierwszy z nich dotyczy wykorzystania zbiorów rozmytych w budowie i modyfikacji harmonogramów budowlanych. Wiele z czynników wpływających na budowę harmonogramu ma charakter trudno kwantyfikowalny i nieprecyzyjny. do rozwiązywania tego typu zadań bardzo dobrze nadaje się logika rozmyta. w wielu pracach podjęto próbę wykorzystania teorii zbiorów rozmytych do budowy harmonogramów budowlanych, co przedstawiono w zwięzłym przeglądzie literatury.

Kolejna część pracy dotyczy elementów zbiorów rozmytych wykorzystanych w budowie harmonogramu. w zaproponowanym przez autorów schemacie wykorzystano pojęcie liczby rozmytej o różnych funkcjach przynależności. Przytoczono również definicję liczby rozmytej oraz podstawowe formuły działań na liczbach rozmytych, które zostały użyte w opracowaniu modelu.

W rozdziale trzecim przedstawiono założenia budowy harmonogramu z wykorzystaniem zbiorów rozmytych. Norma niezbędna do ustalenia czasu realizacji, została określona jako liczba rozmyta o wykresie trapezowym. do określenia ilości robót przyjęto trójkątną funkcję przynależności, zakładając, że wartość funkcji równa 1 to ilość robót wynikająca z przedmiaru robót. Liczbę robotników - w rzeczywistości uzależnioną od wielu czynników, potraktowano jako liczbę rozmytą o wykresie trapezowym. Kalkulację czasu realizacji robót przeprowadzono w oparciu o przytoczone wcześniej formuły matematyczne.

W czwartym rozdziale pracy zaprezentowano przykład działania modelu. Założono, że przedsięwzięcie budowlane odwzorowuje jednopunktowa sieć powiązań z jedną czynnością początkową, oznaczającą rozpoczęcie budowy i z jedną czynnością końcową, oznaczającą zakończenie budowy. Dla wszystkich czynności (robót budowlanych), uwzględnionych w modelu sieciowym przyjęto założenia co do ilości robót, normy czasu pracy oraz ilości pracowników, przypisanych do realizacji zadania.

Przedstawiona metoda rozwiązania rozpatrywanego w artykule polega na dwuetapowym sporządzaniu harmonogramu budowy. w etapie pierwszym sporządza się harmonogram rozmyty, a w etapie drugim na podstawie harmonogramu rozmytego sporządza się harmonogram zwykły - nierozmyty. na podstawie poczynionych założeń przeprowadzono 
kalkulację najwcześniejszych i najpóźniejszych rozmytych terminów realizacji przedsięwzięcia oraz zapasów czasu całkowitego. Następnie po zastosowaniu przyjętego operatora wyostrzenia, który wartościom rozmytych zmiennych przyporządkowuje liczbę rzeczywistą, uzyskano wyniki obliczeń po wyostrzeniu. Wyniki te posłużyły do budowy harmonogramu zwykłego - nierozmytego, ale uzyskanego na podstawie harmonogramu rozmytego. Wszystkie wyniki zostały ujęte w tabelach, a uzyskane na ich podstawie harmonogramy rozmyte dla terminów najwcześniejszych i najpóźniejszych oraz ich wersję po wyostrzeniu również zaprezentowano w artykule.

Dla porównania i pokazania zasadności wykorzystania teorii zbiorów rozmytych w harmonogramowaniu sporządzono również harmonogram tradycyjny, opierając jego budowę na działaniach prowadzonych od początku do końca na liczbach rzeczywistych, deterministycznych. Dla tego samego jednopunktowego modelu sieciowego, chcąc uzyskać zwykły harmonogram realizacji budowy, przyjęto:

- jako normę czasu - średnią normę (obliczoną jako średnią arytmetyczną podanych czterech norm),

- jako liczbę pracowników - stałą deterministyczną (sporządzono dwa warianty dla sześcio- i siedmioosobowej brygady),

- jako ilość robót - ilość wynikającą bezpośrednio z przedmiaru.

Prowadząc obliczenia na liczbach rzeczywistych, można zauważyć, że zarówno norma, jak i ilość robót wynikają i dają się bezpośrednio zaaplikować czy to z posiadanej bazy norm czy z przedmiaru. w takiej sytuacji jedyną wartością, która pozwala na manewrowanie czasem realizacji zadań jest wartość określająca liczbę robotników. Jest to liczba, która poniekąd wypływa z poczynionych przez planistę założeń. Porównując uzyskane wyniki dla harmonogramów deterministycznych, widać, że zmieniając stałą liczbę pracowników tylko o 1, czas realizacji całego przedsięwzięcia ulega zmianie o kilka dni. w odniesieniu do wyostrzonego harmonogramu, uzyskanego na podstawie wyników działań prowadzonych na liczbach rozmytych, czas realizacji jest jeszcze dłuższy.

Założenia przyjęte na etapie planowania realizacji nie mogą być przypadkowe. Jak najwierniejsze odwzorowanie rzeczywistości daje większe szanse na terminowe zakończenie robót. Wykorzystanie zbiorów rozmytych w harmonogramowaniu daje duże możliwości w kwestii uwzględniania czynników wpływających na kształtowanie się wartości czasu realizacji poszczególnych robót. w artykule pokazano założenia i zalety modelu oraz przykład jego działania, jednak temat wymaga dalszego rozwoju i próby przełożenia na bardziej skomplikowane przedsięwzięcie budowlane. 
